\title{
Rabies in primates: are aggressive pet lemurs a risk to humans?
}

Kim E. Reuter', Tara A. Clarkell, III, Marni LaFleurll, IV, Melissa S. Schaeferv, vI

\begin{abstract}
Non-human primates harbor zoonotic pathogens including the rabies virus (Rabies lyssavirus). Though the chances of rabies transmission from primates is low, guidelines currently recommend a post-exposure prophylaxis for unvaccinated persons. In Madagascar, lemurs have been described as carriers of the rabies virus, but a discussion about the risk of rabies transmission to humans from lemurs, particularly in the context of in-country ownership of lemurs, has not been studied. We use qualitative and quantitative data collected from household surveys ( $n=271$ interviewees who had seen a pet lemur across 12 urban towns), web-based surveys ( $n=229$ ), and the literature (publications using data collected by the Institute Pasteur of Madagascar over the last century) to examine the context in which the rabies virus could be transmitted from lemurs to humans. Though only a few wild and pet lemurs in Madagascar have tested positive for rabies, post-exposure treatment is sometimes also sought out following aggressive incidents with lemurs. Many interviewees ( $22 \pm 6 \%$, mean $\pm 95 \%$ confidence interval $\mathrm{Cl}$ ) across 12 towns indicated that pet lemurs they had seen, had a history of aggression. Some lemur owners appear to be aware that their pets could transmit the rabies virus and seek veterinary care to prevent this. The public health burden of rabies is relatively low in Madagascar and despite some anecdotes in the literature, it appears that lemurs are rarely the source of rabies when humans become infected. However, this case study highlights the lack of data and publications regarding the public health implications of human-lemur contact in Madagascar.
\end{abstract}

\section{RÉSUMÉ}

Les primates non-humains hébergent des pathogènes zoonotiques incluant le virus de la rage (Rabies lyssavirus). Bien que les risques de transmission de la rage par les primates soient faibles, les lignes directrices recommandent actuellement une prophylaxie post-exposition pour les personnes non vaccinées. À Madagascar, les lémuriens ont été décrits comme porteurs du virus de la rage, mais une discussion sur le risque de transmission de la rage à l'Homme par les lémuriens, en particulier dans le contexte de la propriété locale des lémuriens, n'a pas été étudiée. Nous

\author{
Correspondence: \\ Kim E. Reuter \\ Conservation International, Gabarone, Botswana \\ Email: kimeleanorreuter@gmail.com
}

utilisons des données qualitatives et quantitatives collectées à partir d'enquêtes auprès des foyers ( $n=271$ interviewés ayant vu un lémurien dans 12 villes), des enquêtes en ligne $(n=229)$ et de la littérature (publications utilisant des données collectées par I'Institut Pasteur de Madagascar au cours du siècle dernier) pour examiner le contexte dans lequel le virus de la rage pourrait être transmis par les lémuriens aux humains. Bien que seuls quelques lémuriens sauvages et animaux de compagnie à Madagascar aient été testés positifs à la rage, un traitement post-exposition est parfois également recherché suite à des agressions par des lémuriens. De nombreuses personnes interrogées $(22 \pm 6 \%$, moyenne \pm Intervalle de confiance IC à 95\%) dans 12 villes ont indiqué que les animaux de compagnie qu'ils avaient vus avaient des antécédents d'agression. Quelques propriétaires de lémuriens semblent être conscients que leurs animaux de compagnie peuvent transmettre le virus de la rage et demander des soins vétérinaires pour éviter cela. La rage constitue une charge relativement faible pour la santé publique à Madagascar et malgré quelques anecdotes dans la littérature, il semble que les lémuriens soient rarement la source de la rage lorsque les humains sont infectés. Cependant, cette étude de cas souligne le manque de données et de publications concernant les implications / conséquences du contact entre humains et lémuriens sur la santé publique à Madagascar.

\section{INTRODUCTION}

Non-human primates (NHPS) are known to harbor a large diversity of zoonotic pathogens and they are often targeted for zoonotic disease surveillance (Levinson et al. 2013). For example, studies have shown that NHPS in all regions of the world can be carriers of the rabies virus (Rabies lyssavirus) (Gautret et al. 2014). The rabies virus, an agent of a lethal encephalitis, is responsible for around 55,000 human deaths every year (World Health Organization 2010). In Africa, rabies causes $\sim 24,000$ human deaths per year with 4 out of every 100,000 people at risk (World Health Organization 2010). Rabies in humans is almost always fatal once clinical signs develop (National Health Service 2017).

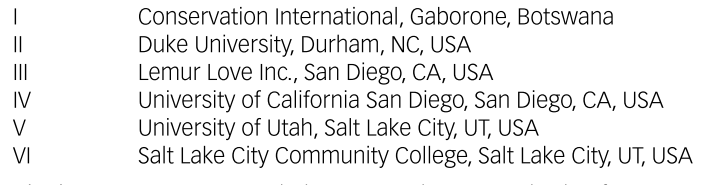

Citation Reuter, K. E., Clarke, T. A., LaFleur, M. and Schaefer, M. S. 2018. Rabies in primates: are aggressive pet lemurs a risk to humans? Madagascar Conservation \& Development 13, 1: 53-59. http://dx.doi.org/10.4314/mcd.v13i1.9 


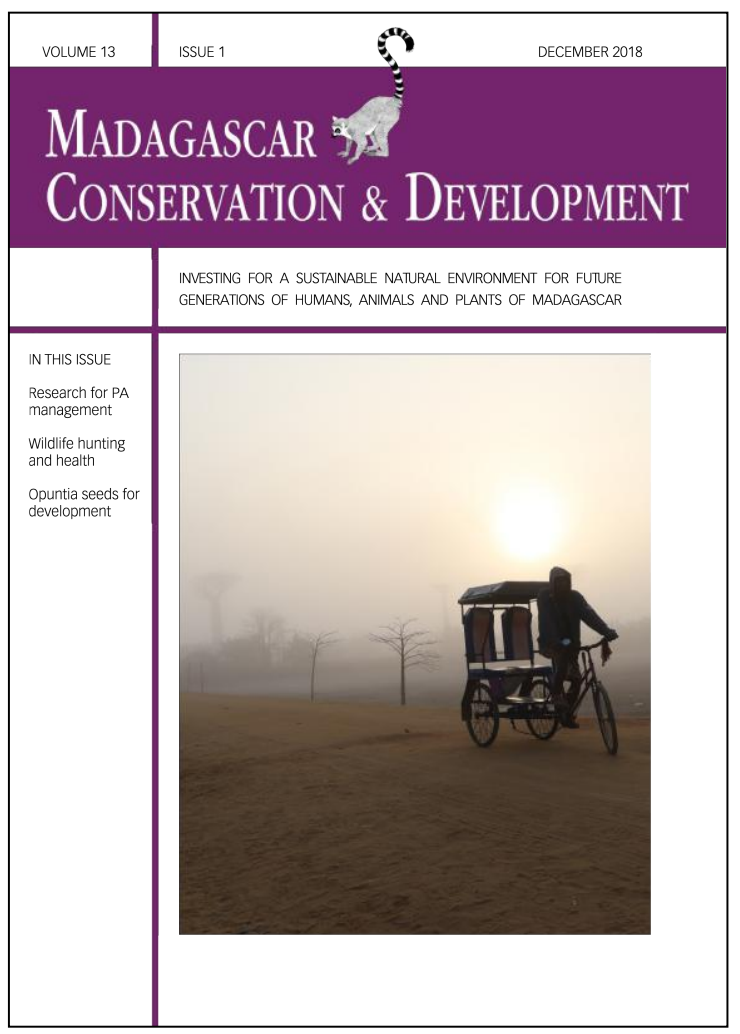

Madagascar Conservation \& Development is the journal of Indian Ocean e-Ink. It is produced under the responsibility of this institution. The views expressed in contributions to MCD are solely those of the authors and not those of the journal editors or the publisher.

All the Issues and articles are freely available at http://www.journalmcd.com

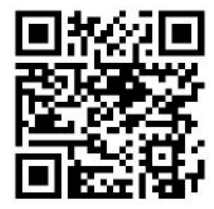

Contact Journal MCD

info@journalmcd.net for general inquiries regarding MCD funding@journalmcd.net to support the journal

Madagascar Conservation \& Development Institute and Museum of Anthropology

University of Zurich

Winterthurerstrasse 190

$\mathrm{CH}-8057$ Zurich

Switzerland

Indian Ocean e-Ink

Promoting African Publishing and Education

www.ioeink.com

Missouri Botanical Garden (MBG)

Madagascar Research and Conservation Program

Missouri Botanical Garden

BP 3391

Antananarivo, 101, Madagascar 
When humans interact with NHPs (e.g., via pet ownership, tourism encounters, in the process of capturing an animal for bushmeat) there are opportunities for the exchange of pathogenic organisms (reviewed by Muehlenbein 2017), such as the rabies virus. Though the chances of rabies transmission from primate bites or scratches are low (Health Protection Agency 2013), when bites/scratches occur, guidelines typically recommend a postexposure prophylaxis (PEP) for unvaccinated persons (Health Protection Agency 2013). In these cases, the World Health Organization (2010) recommends the provision of both a vaccine and the rabies immunoglobulin in response to severe injuries (e.g., transdermal bites or scratches; licks on broken skin or mucous membrane) and just the vaccine in response to minor injuries (minor scratches or abrasions without bleeding) from wild animals. A 2014 review (Gautret et al. 2014) concluded that, "a large number of international travelers sustain NHP-related injuries during their trips" ( $p$ 6). The study hypothesized that "underreporting of rabies in NHPs is likely to be significant" (p 4).

In Madagascar, the rabies virus is found across the entire island (Morvan et al. 1993, Reynes et al. 2011). Dogs and cats are the two-most commonly suspected vectors for rabies transmission to humans in Madagascar; in 1998, dogs were suspected as the source of potential rabies exposure in $93 \%$ of consultations in which a person received PEP treatment for rabies ( $n=5,165$ people in Madagascar; Zeller et al. 1999). In cases where animals are tested for rabies (after a human receives PEP treatment following an interaction with the animal), cattle, pigs, and dogs test positive more than $50 \%$ of the time for rabies (Andriamandimby et al. 2013). Some wild animals in Madagascar have been noted as potential rabies carriers for humans (including bats, Andriamandimby et al. 2013) and the risk from these animals is recognized by entities like the Center for Disease Control (2017).

Madagascar's endemic primates - the lemurs - can be infected with the rabies virus (this having been experimentally confirmed prior to the 1930s, Girard 1930: 15; cited by Jennings 2009; one lemur - out of 26 lemurs tested - tested positive for rabies, Zeller et al. 1999; four laboratory confirmed cases in lemurs in 1994 in Madagascar, Tsiresy 1995 cited in Gautret et al. 2014). It has been hypothesized that lemurs could contract rabies from feral and pet dogs, before transmitting the virus to humans (Coulanges et al. 1974), but it is not clear that this is a frequent occurrence. Wild lemurs rarely come into contact with domestic or feral dogs, where they might contract rabies (Coulanges et al. 1974). However for pet lemurs, it was previously though that captive/pet lemurs are kept away from humans (i.e., in a cage) or well supervised (i.e., away from dogs) (Coulanges et al. 1974) but more recent research indicates that $28 \%$ of lemurs seen in captivity are kept as habituated animals (i.e., not restrained) with more freedom of movement than caged or restrained lemurs (Reuter and Schaefer 2016).

The potential transmission of rabies from lemurs to humans has been studied only as an aside to the study of rabies transmission to humans from dogs, cats, bats, and cattle (e.g., Coulanges et al. 1974, Zeller et al. 1999, Reynes et al. 2011, Andriamandimby et al. 2013). The risk of humans contracting rabies from lemurs has been considered very low (Coulanges et al. 1974). However, human-lemur contact, where rabies transmission might occur, is common in the context of illegal pet lemur ownership within Madagascar's tourism industry (Reuter and Schaefer 2016, Reuter and Schaefer 2017a). In Madagascar, which was visited by 222,000 tourists in 2014 (World Tourism Organization 2014), there are thousands of lemurs kept in illegal captivity (Reuter et al. 2016). In many cases, these lemurs are kept for the purpose of moneymaking from the tourism industry (Reuter and Schaefer 2017a). For example, tourists might pay money to take a photo with a lemur or feed a lemur a banana, or lemurs might be kept as an 'added value' attraction at restaurants and/or hotels (Reuter and Schaefer 2017a). As such, many tourists will encounter captive, semi-captive, or habituated but wild lemurs (at hotels, restaurants, in private and public reserves, national parks, and in other public areas such as on the beach) where human-lemur interactions are often encouraged (Reuter and Schaefer 2017a).

In some cases, captive lemurs are reportedly aggressive with their human owners or with tourists (Reuter and Schaefer 2017b). It is through these aggressive incidents, which can result in bites and scratches, that the rabies virus could be transmitted. Unfortunately, even when aggressive incidents are not due to rabies (i.e., not due to heightened aggression during the so-called 'furious rabies' stage, Coulanges et al. 1974), the inability to know with certainty whether a lemur is infected with rabies means that humans are encouraged to seek PEP treatment whenever these types of incidents occur (Coulanges et al. 1974). Interactions with NHPs result in numerous tourists needing to receive preventative post-exposure treatment every year. In France, of the 424 patients visiting a rabies clinic (including people returning from travels abroad), almost $20 \%$ were injured by nonhuman primates, including lemurs (Gautret et al. 2010).

It is clear that gaps in our knowledge remain with respect to rabies transmission to humans via lemurs. Prior review papers on the disease ecology of wild lemurs do not mention rabies (e.g., Junge and Sauther 2006). In addition, no publication has focused exclusively on rabies transmission from lemurs to humans and as noted below, the publications on the topic (e.g., published by, or with data from, the Institute Pasteur of Madagascar [IPM]) are difficult to access. For example, a global review on the rabies virus in NHPS (Gautret et al. 2014) found little information on this topic from Africa and cited just one conference presentation on the subject for Madagascar (Tsiresy 1995; having apparently not come across any of the IPM publications). Therefore, given the large and increasing number of tourists visiting Madagascar (World Tourism Organization 2014), and the high number of lemurs being kept in captive conditions where they are encouraged to directly contact humans (Reuter et al. 2016), there is a need to revisit the issue of disease transmission between humans and lemurs.

\section{METHODS}

QUANTITATIVE DATA. The data presented in this paper include information collected from household surveys as well as data from IPM publications (from the years 1898 to 2016).

Household surveys. Data were collected in 12 towns (Table 1) in central, southern, and eastern Madagascar in July to August 2016 (see Reuter et al. 2018 for full methods on survey administration). Data collection took place in both urban and rural areas using 627 household surveys. We used stratified random sampling within towns and interviewed no more than one adult per household to ensure independent sampling. Interviews were anonymous, no identifying information was collected, and respondents received no compensation for their participation. Interviews took an average of $\sim 10$ minutes. Verbal informed consent was received, and interviews were conducted by a 2-person team com- 
posed of one international project leader and one trained Malagasy translator (see Acknowledgements). Questions were asked in the local Malagasy dialect with the semi-structured nature of the interview allowing for clarifying questions to be posed in French or Malagasy as needed. A full list of interview questions can be found in Reuter et al. (2018), and included (among other questions): (i) Have you seen a pet lemur? (ii) Was the lemur aggressive? If yes, how? (iii) Do you know how pet lemur ownership ended? Following Reuter et al. (2016), we did not provide interviewees with a definition of a 'pet lemur' though the researchers' definition of what constitutes a pet lemur can be found in Reuter et al. (2016). We excluded lemurs seen in zoos or reserves.

International standards for research ethics were followed and research was approved by an ethics oversight committee (Institutional Review Board, University of Utah). Research followed all national and local laws pertaining to the survey of adults in Madagascar. Research was authorized by locally elected officials in every town and commune in which research took place. This research required no government permits.

Data published by the Institute Pasteur of Madagascar. Since 1901, the Institute Pasteur of Madagascar [IPM] has provided rabies services to the public in Madagascar. IPM reported the first lemur suspected as being the vector of rabies in 1910 (Girard 1930: 905 as cited in Jennings 2009). Since 1939, anti-rabies services have been provided to the Malagasy public nationwide via the Center for Anti-Rabies Treatment (CTAR) within the IPM. CTAR supplies rabies vaccines to all anti-rabies treatment centers in Madagascar, provides rabies treatment to humans free of charge, and tests animals suspected of being the source of the rabies virus. In many cases, the IPM's annual reports provide a historical record of the number of rabies cases treated nationally each year in Madagascar, as well as the number of cases that are attributed to lemurs (both wild and captive); however, the most recent annual reports do not include this level of detail.

We present information taken from the annual reports for IPM (via the IPM website) or where data from the IPM had been published by other authors in secondary literature (Table S1). Many of the IPM reports are accessible only via the archives in Madagascar or in Paris, France and are not available through interlibrary loan; therefore, much of this information is not in the public domain. We present what information we have been able to access through the above-noted, online literature search.

Analysis. For household surveys, as there may be greater variation between than within towns, interviewees were used as subsamples within each study site for most analyses and towns were used as replicates; therefore, when results are presented as mean values with $95 \%$ confidence intervals, towns are used as replicates.

QUALITATIVE DATA. In addition to the quantitative data reported, above, we present some qualitative information recorded from 229 web-based surveys about pet lemurs in Madagascar (administered in 2015 and 2016). The methods and a broader investigation into the results of the surveys have been published in Reuter and Schaefer (2016, 2017a,b). These webbased surveys asked people to provide different pieces of information about the pet lemurs that they had seen in Madagascar; in some instances, respondents provided detailed information about the context of lemur ownership. Select quotes from respondents are provided, below.

\section{RESULTS}

PARAMETERS OF THE DATASET. In 2016, household interviews across the 12 towns yielded 271 individuals who had seen a pet lemur (Table 1). These individuals provided information on whether the pet lemurs were known to be aggressive.

IPM data taken from primary and secondary publications included relevant information from the years 1898 to 2016 (Table S1). These data indicate that nationally, 566 people in 1960 (Source C, Table S1), and at least 4,022 people per year from 1998 onwards (Sources E and F-N, Table S1), received PEP rabies treatment following potential exposure to the virus (Figure 1a). Most

Table 1. The proportion of respondents across 12 towns who reported about a pet lemur that had been/was aggressive towards humans.

\begin{tabular}{lccc}
\hline Town (French name) & $\begin{array}{c}\text { Number of } \\
\text { people } \\
\text { interviewed }\end{array}$ & $\begin{array}{c}\text { Number of } \\
\text { people who had } \\
\text { seen a pet } \\
\text { lemur }\end{array}$ & $\begin{array}{c}\text { Percent of } \\
\text { respondents } \\
\text { indicating that } \\
\text { the lemur had a } \\
\text { history of } \\
\text { aggression }\end{array}$ \\
\hline Ambositra & 99 & 44 & $23 \%$ \\
Anakao & 40 & 33 & $6 \%$ \\
Andasibe & 53 & 3 & $33 \%$ \\
Antananarivo & 54 & 11 & $27 \%$ \\
Antsirabe & 51 & 22 & $32 \%$ \\
Beforona & 54 & 6 & $33 \%$ \\
Efotse & 9 & 8 & $13 \%$ \\
Fianarantsoa & 84 & 50 & $32 \%$ \\
Tôlanaro (Fort-Dauphin) & 50 & 31 & $10 \%$ \\
Moramanga & 60 & 23 & $26 \%$ \\
Toamasina (Tamatave) & 50 & 23 & $17 \%$ \\
Toliara (Tulear) & 23 & 17 & $12 \%$ \\
\hline Total & 627 & 271 & $22 \pm 6 \%$
\end{tabular}
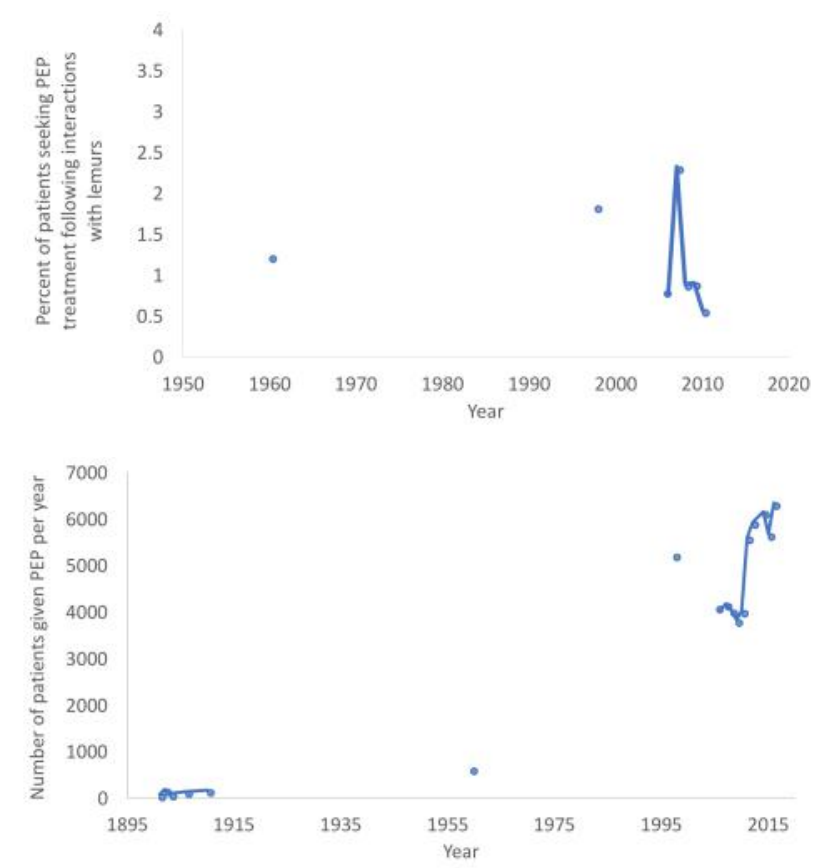

Figure 1. The number of patients given PEP rabies treatment by IPM following potential exposure to the virus, at a national level (a) and the percent of rabies patients who received PEP treatment because of an interaction with a lemur (whether captive or wild) (b). Note that data for figure (b) were not available for all years where data for figure (a) could be found. Lines are drawn between points where there are two or more continuous years of data available. $\dagger$ For (a), data taken from Sources B, C, E, and G-P (Table S1). For (b), data taken from Sources C $E, G, H, I, J$, and $K$ (Table S1). 

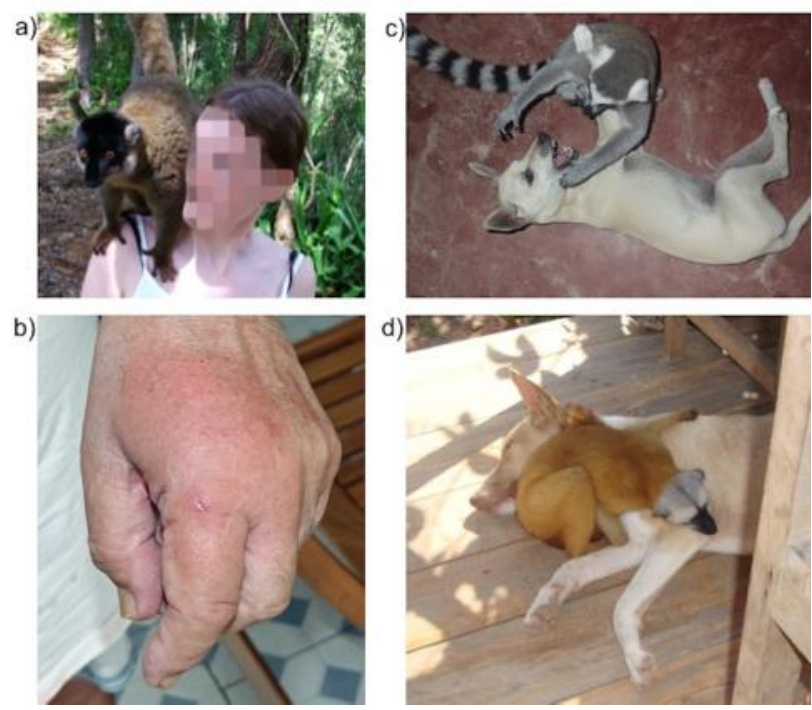

Figure 2. Photographs submitted to the Pet Lemur Survey showing a typical human-lemur encounter by a tourist (a), a scar on the hand of a pet lemur owner in Madagascar from a lemur bite (b), and two different habituated pet lemurs (owned by two different owners) interacting with domestic dogs (c,d).

individuals $(63 \%$ in $1902,58 \%$ in $1910,77 \%$ in 1960 , and between 90\% - 97\% from 2006 to 2015; Sources B, C, E, G-O, respectively in Table S1) received their PEP treatment in the greater Antananarivo area.

TRANSMISSION FROM DOGS TO LEMURS. We do not have quantitative data on how often lemurs come into contact with feral or domestic dogs (Figure 2). However, there are several anecdotes collected via the web-based surveys that help clarify how pet lemurs might be exposed to the rabies virus from feral and pet dogs, and subsequently infect humans.

Several respondents to the web-based survey described lemurs being kept on leashes where they could not escape village dogs (Figure 2). One respondent wrote: "They kept [the lemur] tied to a post with a rope around his middle because he often tried to bite the children and the dogs." Another wrote: "There were several [lemurs] at a home in the village which were tied with rope around their waists with only a couple of feet allowance to move (no cage). [The lemurs] had frequent diarrhea... They were incredibly stressed and had no way to hide or get away from people, dogs, etc."

In other instances, lemurs - even on leashes - had relatively friendly relationships with some, but not all, dogs. "One adult lemur was kept on a leash. The place also had a dog that the leashed lemur would try to leap at, but with the (short) leash on, it would just fruitlessly jump over and over and over and over again, swinging like a pendulum, while the dog stood just out of range. I did see the lemur at night once snuggled closely with another dog, so...maybe it just didn't like this one particular dog or it wanted to wrestle. Humans could go up and hold and pet the lemur and the lemur would be calm, but when the dog appeared the lemur would go crazy after the dog again." The anecdotes provide evidence that some pet lemurs could conceivably be bitten/bite a dog and then, in turn, bite humans.

LEMURS AS CARRIERS OF THE RABIES VIRUS As part of their rabies. surveillance services, IPM conducts rabies tests on animals when the patient being given PEP or being treated for ra- bies can identify the animal suspected of being the source of the viral infection. IPM records indicate that 150 lemurs were tested for rabies since 1898 (total number of lemurs tested is unclear given overlaps in the year-ranges considered by different sources; Table S2). Of the lemurs tested, only one lemur (between 1994 and 1998) tested positive for rabies (another publication noted that four lemurs in Madagascar were laboratory confirmed to have rabies in 1994, though it is not clear whether these were the same lemurs tested by IPM, Tsiresy 1995 as cited in Gautret et al. 2014). In addition, between 1910 and 1913, seven lemurs were recorded as testing positive for rabies but Coulanges et al. (1974) has hypothesized that six of these individuals should be considered false positives. The reasoning provided in Coulanges et al. (1974) is that no lemurs had been found to be positive for rabies between 1954 and 1973 and that, therefore, 6 or 7 of these earlier 'positive' tests likely were incorrect, as they were all made by one observer during 1910 and 1913. In comparison, dogs that have bitten or scratched humans (and where the human seeks rabies treatment), test positive between $42 \%$ to $69 \%$ of the time (Table S2).

Some pet lemur owners appear to be aware that lemurs can be carriers of the rabies virus. In the web-based survey, one veterinarian in central Madagascar indicated that "at the vet clinic, we have some clients from the South who bring lemurs to vaccinate against rabies...even if having pet lemurs is against the law, as a clinic, we cannot refuse to treat them." However, not all owners are able to find veterinarians who are willing or knowledgeable enough to treat their pet lemurs. One entity in Madagascar (visited in 2016 as part of our household surveys) that had two lemurs on the premises without permits (although they were caring for lemurs that had been kept as pets initially by someone else) indicated that they had difficult time securing veterinarian care for their lemurs (see Reuter et al. 2018 for more information).

TRANSMISSION FROM LEMURS TO HUMANS. TO transmit the rabies virus to humans, lemurs must lick, bite, or scratch humans and such aggressive interactions were reported in our survey. In our household surveys, $22 \pm 6 \%( \pm 95 \% \mathrm{Cl}, \mathrm{n}=12$ towns as replicates) of respondents who had seen a pet lemur reported that the pet lemur had a history of aggression (Table 1). A few respondents ( $n=11$ individuals) provided additional context for the lemur's aggression: the lemur was aggressive towards individuals that were not its owner $(n=4)$; the lemur had bitten adults and children ( $n=2)$; the lemur was aggressive when outside a cage and/or is caged because it is aggressive $(n=2)$; the lemur became aggressive during reproductive season $(n=1)$; the lemur became aggressive when it matured into an adult $(n=1)$; and the lemur was aggressive when someone accidentally stood on its tail $(n=1)$.

Lemurs are rarely cited as a potential source for rabies when humans seek PEP treatment in Madagascar. In 1960, 1.24\% of the individuals treated at IPM cited lemurs as the reason for needing PEP rabies treatment (Figure 1b). From 2006 to 2010, this percentage ranged between $0.57 \%$ in 2010 to $2.32 \%$ in 2007 (Figure 1b). Both wild and pet lemurs have been cited as the reason for needing PEP rabies treatment, with $23 \%$ to $61 \%$ of people noting that the lemur was a pet (Table S3).

The lemurs' owners are not the only ones that are affected. One tourist, who had visited an "island where [lemurs] are being fed bananas by tourists" reported in our web-based survey that the lemurs were "quite aggressive." The respondent further noted: 
"my husband was bitten (later requiring rabies shots) and I was scratched."

\section{DISCUSSION}

In this paper, we use rabies as a case study for examining how disease transmission might take place between lemurs and humans in Madagascar. Though the risk from rabies is low, we use quantitative and qualitative data to elaborate on how transmission of the rabies virus from lemurs to humans might take place. The risk of rabies transmission from lemurs to humans is not unique to Madagascar; nine other African countries have primates that carry rabies (Gautret et al. 2014). However, what is unique about the case of lemurs in Madagascar, at least for the African continent, are the in-depth data that have been collected over the past century in Madagascar by the IPM (Jennings 2009). These data, combined with our surveys on captive lemurs in Madagascar, provide an interesting case study for examining the potential risk of rabies in the context of pet primate ownership.

RABIES IN MADAGASCAR. There are approximately four to ten confirmed cases of human rabies each year in Madagascar with most cases in urban areas, especially near the capital of Antananarivo. Rabies cases in rural areas are likely underreported (Andriamandimby et al. 2013). In 2016, there were 6,338 people given PEP rabies treatment following potential exposure to the rabies virus (Institut Pasteur de Madagascar 2017). The primary vector of rabies in Madagascar is typically roaming dogs (Jennings 2009; Sources G-P in Table S1). It has been noted that the human victims of rabies are often children, because they play outdoors and therefore come into contact with dogs, the disease's main carrier (Jennings 2009). The Center for Disease Control (2017) notes that children are at risk because they "tend to play with animals, might not report bites" and "their smaller stature...makes severe bites to high-risk areas, such as the face and head, more likely." However, partly because of nationwide vaccination efforts and the provision of PEP before clinical signs appear, the number of deaths every year are low.

RABIES AND LEMURS. It appears possible that lemurs could get rabies from both dogs (Coulanges et al. 1974), fossa (Cryptoprocta ferox), and potentially other animals known to carry rabies. In terms of lemur contact with dogs, there is evidence of feral and domestic dogs making inroads into areas where wild lemurs would roam. For example, $41 \%$ of domestic dogs around the Ranomafana National Park had reportedly killed a wild animal, sometimes on a weekly basis (Valenta et al. 2016). Regarding fossa, a man in Ihosy contracted rabies from a fossa bite in 2007 (Institut Pasteur de Madagascar 2007). The sample taken from this fossa was tested by the Institute Pasteur Paris, which determined that it was "very close to the canine rabies strains in Madagascar" (Institut Pasteur de Madagascar 2007). It is therefore feasible that lemurs could also contract rabies from fossa prior to passing the virus along to humans.

Nevertheless, the percentage of lemurs carrying the rabies virus appears to be very low (Table S2) though few lemurs have been tested. For example, IPM records indicate that only 150 lemurs have been tested for rabies since 1898 (Table S2), which is much lower than the number of people who thought they might have been exposed to rabies from a lemur (Table S3) and much lower than the number of animals tested by IPM in total (Table S2).
It was noted that in the past, the number of animal specimens tested by IPM was low though efforts were made in 1997 "to encourage veterinarians to ask for rabies diagnosis in suspicious animals free of charge" (Zeller et al. 1999: 59). Most annual IPM reports still make mention of the difficulties around collecting, transporting, and testing samples and also continue to note that few samples from areas outside of Antananarivo are tested (e.g., Institut Pasteur de Madagascar 2016, 2017). A recent IPM annual report noted that veterinarians often do not have the resources to send samples for testing (Institut Pasteur de Madagascar 2007) even though the testing itself is a free service.

RABIES TRANSMISSION FROM LEMURS TO HUMANS. There is a potential for both wild and pet lemurs to transmit rabies to humans. There are numerous reports in the literature of international tourists to Madagascar seeking PEP rabies treatment upon returning home following being bitten by a lemur (Folb and Cooke 2006, Gautret et al. 2010). There are many anecdotes of highly habituated, wild lemurs in national parks (and private/public reserves) jumping onto tourists in search of food (e.g., lemurs in the Ankarana National Park, KER pers. obs.). In the Bradt travel guide, an anecdote regarding an infant-carrying, female Lemur catta who bit a tourist in self-defense (Bradt 2007: 124) is used to illustrate the value of seeking rabies vaccinations prior to travel for 'peace of mind', and because medical treatment may be difficult to obtain.

While the data collected by IPM show that people more frequently seek PEP rabies treatment following interactions with wild lemurs (rather than to pet lemurs, Table S3), captive lemurs could still contract rabies and transmit it to humans. In 1993, a rabies case was described in the IPM dataset that involved a captive ring-tailed lemur (L. catta) at a tourism resort that had been in contact with many dogs suggesting that the virus was transmitted from dog to lemur (Zeller et al. 1999). As another example, a wellknown lemur researcher was quoted as stating that, "the chances [of being infected by rabies from a lemur] are so small that I wouldn't dream of getting rabies shots after a lemur bite...the chance of a rabid dog catching a lemur which then got away seem not worth worrying about - except in one circumstance. If the lemur was hand-raised, either a current pet or a pet released into the wild, it may attack a human without provocation" (Bradt 2007: 124). The threat of rabies transmission from pet primates to humans is not limited to lemurs. For example, a study of U.S. soldiers stationed in Afghanistan found that over a 4-month period, 8 of 10 bites from NHPS requiring preventative rabies treatment were from pet monkeys (Mease and Baker 2012).

\section{IMPLICATIONS}

The number of lemurs that have tested positive for rabies is extremely low, and therefore the risk of humans contracting rabies from lemurs does not appear to be high. Yet, Madagascar is somewhat unique in that injured travelers attending a rabies treatment center in France for PEP treatment were five times more likely to be seeking treatment due to an encounter with a primate in Madagascar compared to North Africa, the rest of subSaharan Africa, Latin America, and the Middle East ( $n=424$ injured travelers attending a rabies treatment center in Marseille, France between 1994 and 2007, Gautret et al. 2010).

There are several factors that could potentially lead to an increase in the number of cases of humans contracting rabies from 
both wild and pet lemurs in the future. First, the amount of contact between wild and pet lemurs and dogs could increase. Increasing human population of Madagascar (2-3\% increase/year, United Nations 2017) could be accompanied by an increase in the number of dogs on the island (as the African human population increases, so does the dog population, Cleaveland 1998). An increase in Madagascar's dog population could lead to increased contact between dogs and wildlife (Cleaveland 1998). Dogs in Madagascar are known to venture into forests and sometimes attack wild animals (Valenta et al. 2016), which could result in an increase in the number of wild lemurs contracting rabies. Second, lemurs could become more susceptible to diseases in the future. Madagascar's increasing human population size could lead to further habitat degradation, thereby placing stress on the lemurs and making them more susceptible to diseases such as rabies (Junge and Sauther 2006). Given that the rabies virus appears to have been introduced to Madagascar around 1840 (Jennings 2009), lemurs may have little immunity to the virus, and lemurs in general are highly susceptible to new diseases (Junge and Sauther 2006). Third, lemur-human contact could increase in the future. The increasing population in Madagascar could bring more people into contact with lemurs (Junge and Sauther 2006). In addition, an increase in the number of tourists visiting Madagascar could place more humans in contact with lemurs as tourists pay to feed lemur and/or take photos with lemurs (Reuter and Schaefer 2017a). A study of all Danish travelers traveling to rabies-endemic countries from 2000 to 2012 indicated that increases in the use of Pre-exposure prophylaxis (PrEP) and PEP could be explained by the increased rate of traveling, and not by an increased awareness of rabies risk or more bites per traveler (Christiansen et al. 2016).

The number of travelers exposed to rabies by NHPS and receiving PEP has been increasing (Gautret et al. 2014). The Danish study also found annual increases of $8.2 \%$ and $8.8 \%$ of PrEP and PEP usage, respectively, from 2000 to 2012 (Christiansen et al. 2016). In other studies, bites from NHPs, including lemurs, accounted for up to $20 \%$ of international travelers seeking PEP rabies treatment, with most being injured from bites (Gautret et al. 2010). Additionally, Riesland and Wilde (2015) suggest that, of people seeking treatment for rabies, tourists are bitten by NHPs more often when compared to locals. In one survey of 3,845 tourists at four international locations for primate-based tourism, most tourists knew they could get diseases from wild primates and yet still touched or fed primates when given the opportunity (Muehlenbein 2017). In Madagascar there are likely thousands of human-lemur interactions by tourists every year (e.g., Reuter and Schaefer 2016, 2017b) despite travel guidelines advising against the touching of these animals. For example, the Consulate General of France specifically advises that both residents and expatriates living in Madagascar should not touch cats, dogs, and lemurs because of the risk of rabies (Le Brun and Randrianarison 2014).

Since Madagascar's population is increasing, it would not be surprising if the number of pet lemurs (estimated at 28,000 between 2010 and 2013; Reuter et al. 2016) also increased, though no data on whether pet lemur ownership has increased, decreased, or remained stable exist. Our household surveys indicate that aggression towards humans, including bites and scratches, is not uncommon (approximately $22 \%$ of individuals who had seen a pet lemur reported it was aggressive) which could potentially increase the rate of rabies transmission. Though the risk of getting rabies from lemurs may currently be low, individuals should still take prophylactic precautions (Coulanges et al. 1974; Christiansen et al. 2016).

\section{FUTURE RESEARCH}

It has been noted that the "animal trade for the purpose of exotic pet ownership will continue to facilitate the emergence of infectious diseases" (Muehlenbein 2017: 35). We suspect that this is also true for lemurs in Madagascar. It is likely that lemurs are carriers for other viruses that are of greater public health concern than the rabies virus, but the data needed to evaluate their role in transmitting those diseases likely do not exist. For viruses alone, lemurs were "directly implicated" in an outbreak of the Chikungunya in Madagascar in 2005-2006, described as "an amplifying reservoir host" for Yellow Fever, and carry the human-mediated herpesvirus (reviewed by Barrett 2011). Notably, changes in the environment - such as is expected with climate change - are anticipated to change lemur (Brown and Yoder 2015) and parasite distributions (including viruses, Barrett 2011). Therefore, additional research is needed to better inform the impacts of pet lemur ownership on the transmission of diseases between humans and lemurs.

\section{ACKNOWLEDGMENTS}

Thanks to two anonymous reviewers and the editor, Dr. Erik Patel, for providing feedback that substantially improved the quality of the text. Many thanks to the Groupe d'étude et de recherche sur les primates de Madagascar, Association Mitsinjo, Sainte Luce Reserve, and to Conservation International for facilitating research in some of the towns visited. Many thanks to Sahondra Hanitriniaina, Tiana Ratolojanahary, Irène Ramanantenasoa, Housseini Maihidini, Tokihenintsoa Andrianjohaninarivo, Tolotra Fanambinantsoa, Honore Reseva, and Olivier Zarason for serving as translators during part of the data collection. Thanks to Jacky Youssouf for assisting with the logistics for data collection in Toliara and Anakoa. We thank host communities for their hospitality. This research was funded by a National Geographic Conservation Trust grant to KER.

\section{REFERENCES}

Andriamandimby, S. F., Héraud, J. M., Ramiandrasoa, R., Ratsitorahina, M., Rasambainarivo, J. H., et al. 2013. Surveillance and control of rabies in La Reunion, Mayotte, and Madagascar. Veterinary Research 44: \#77. <https://doi.org/10.1186/1297-9716-44-77>

Barrett, M. A. 2011. Understanding Environmental and Anthropogenic Drivers of Lemur Health in Madagascar: The Importance of a One Health Perspective. Unpubl. Doctoral Dissertation. Duke University, Durham. Available at <https://dukespace.lib.duke.edu/dspace/handle/10161/3885>

Bradt, H. 2007. Madagascar: the Bradt travel guide. Bradt Travel Guides Ltd., U.K.

Brown, J. L. and Yoder, A. D. 2015. Shifting ranges and conservation challenges for lemurs in the face of climate change. Ecology and Evolution 5, 6: 1131-1142. <https://doi.org/10.1002/ece3.1418>

Centers for Disease Control and Prevention. 2017. Health Information for Travelers to Madagascar. Available at <https://wwwnc.cdc.gov/travel/destinations/traveler/none/madagascar> accessed 21 May 2017.

Christiansen, A. H., Rodriguez, A. B., Nielsen, J. and Cowan, S. A. 2016. Should travellers to rabies-endemic countries be pre-exposure vaccinated? An assessment of post-exposure prophylaxis and pre-exposure prophylaxis given to Danes travelling to rabies-endemic countries 2000-12. Journal of Travel Medicine 23, 4: 1-6. <https://doi.org/10.1093/jtm/taw022> 
Cleaveland, S. 1998. Epidemiology and control of rabies. The growing problem of rabies in Africa. Transactions of the Royal Society of Tropical Medicine and Hygiene 92, 2: 131-134. <https://doi.org/10.1016/S0035-9203(98)90718-0>

Coulanges, P., Rakotonirina-Randriambeloma, P.-J. and Brygoo, E.-R. 1974. La rage à Madagascar. vingt ans d'utilisation d'un vaccin antirabique phéniqué type fermi avec virulence résiduelle. Archives de I'Institut Pasteur de Madagascar 43: 149-179. Available at <https://bit.ly/2LNPSAX>

Folb, J. E. and Cooke, R. P. 2006. Issues of human rabies immunoglobulin and vaccine: policy versus practice. Journal of Public Health 29, 1: 83-87. <https://doi.org/10.1093/pubmed/fdl079>

Girard, G. 1930. L'Institut Pasteur de Tananarive. Imprimerie Moderne de l'Emyrne, Antananarivo, Madagascar.

Gautret, P., Adehossi, E., Soula, G., Soavi, M.-J., Delmont, J., et al. 2010. Rabies exposure in international travelers: do we miss the target? International Journal of Infectious Diseases 14, 3: e243-e246. $<$ https://doi.org/10.1016/j.jijid.2009.05.009>

Gautret, P., Blanton, J., Dacheux, L., Ribadeau-Dumas, F., Brouqui, P., et al. 2014 Rabies in nonhuman primates and potential for transmission to humans: a literature review and examination of selected French national data. PLOS Neglected Tropical Diseases 8, 5: e2863. <https://doi.org/10.1371/journal.pntd.0002863>

Health Protection Agency. 2013. Guidelines on Managing Rabies Post-Exposure Prophylaxis: January 2013. Available at <http://www.hpa.org.uk/webc/HPAwebFile/HPAweb_C/1224745729371> Accessed 7 Feb 2013.

Institut Pasteur de Madagascar. 2007. Rapport d'Activités 2007. Institut Pasteur de Madagascar, Antananarivo, Madagascar. Available at <http://www.pasteur.mg/publication/rapport-dactivites-2007/>

Institut Pasteur de Madagascar. 2016. Rapport d'Activités 2015. Institute Pasteur Madagascar, Antananarivo, Madagascar. Available at $<$ http://www.pasteur.mg/publication/rapport-dactivites-2015/>

Institut Pasteur de Madagascar. 2017. Rapport d'Activités 2016. Institute Pasteur Madagascar, Antananarivo, Madagascar. Available at <http://www.pasteur.mg/publication/rapport-dactivites-ipm-2016/>

Jennings, E. T. 2009. Confronting rabies and its treatment in colonial Madagascar, 1899-1910. Social History of Medicine 22, 2: 263-282. <https://doi.org/10.1093/shm/hkp010>

Junge, R. E. and Sauther, M. L. 2006. Overview of the health and disease ecology of wild lemurs: conservation implications. In: Lemurs Ecology and Adaptation. L. Gould and M. L. Sauther (eds.), pp 423-440. Springer Science and Business Media, New York, NY, USA.

Le Brun, Y. \& Randrianarison, A. 2014. Conseils sanitaires aux résidents ou expatriés à Madagascar. Consulat Général de France à Tananarive, Madagascar. Available at <https://bit.ly/2LnRfR2>

Levinson, J., Bogich, T. L., Olival, K. J., Epstein, J. H., Johnson, C. K., Karesh, W. and Daszak, P. 2013. Targeting surveillance for zoonotic virus discovery. Emerging infectious diseases 19, 5: 743-747. <https://doi.org/10.3201/eid1905.121042>

Mease, L. E. and Baker, K. A. 2012. Monkey bites among US military members, Afghanistan, 2011. Emerging Infectious Diseases 18, 10: 1647-1649. <https://doi.org/10.3201/eid1810.120419>

Morvan, J. M., Rakoto-Andrianarivelo, M., Randriamihoatra, S. \& Roux, J. 1993. Situation de l'endémie rabique à Madagascar. Archives de l'Institut Pasteur de Madagascar 60, 1-2: 5-8.

Muehlenbein, M. P. 2017. Primates on display: potential disease consequences beyond bushmeat. American Journal of Physical Anthropology 162, S63: 32-43. <https://doi.org/10.1002/ajpa.23145>

National Health Service. 2017. Rabies. Available online at <http://www.nhs.uk/Conditions/Rabies/Pages/Introduction.aspx> Accessed 22 May 2017

Reuter, K. E. and Schaefer, M. S. 2016. Captive conditions of pet lemurs in Madagascar. Folia Primatologica 87, 1: 48-63. <https://doi.org/10.1159/000444582>

Reuter, K. E. and Schaefer, M. S. 2017a. Motivations for the ownerships of captive lemurs in Madagascar. Anthrozoös 30, 1: 33-46. <https://doi.org/10.1080/08927936.2017.1270589>
Reuter, K. E. and Schaefer, M. S. 2017b. Illegal captive lemurs in Madagascar: comparing the use of online and in-person data collection methods. American Journal of Primatology 79, 11: e22541. <https://doi.org/10.1002/ajp.22541>

Reuter, K. E., Gilles, H., Wills, A. R. and Sewall, B. J. 2016. Live capture and ownership of pet lemurs in Madagascar: extent and conservation implications. Oryx 50, 2: 344-354. <https://doi.org/10.1017/S003060531400074X>

Reuter, K. E., Clarke, T. A., LaFleur, M., Ratsimbazafy, J., Holiniaina Kjelgaard, F., et al. 2018. Exploring the role of wealth and religion on the ownership of captive lemurs in Madagascar using qualitative and quantitative data. Folia Primatologica 89, 1: 81-96. <https://doi.org/10.1159/000477400>

Reynes, J. -M., Andriamandimby, S. F., Razafitrimo, G. M., Razainirina, J., Jeanmaire, E. M., et al. 2011. Laboratory surveillance of rabies in humans, domestic animals, and bats in Madagascar from 2005 to 2010. Advances in Preventive Medicine 2011: \#727821. <http://dx.doi.org/10.4061/2011/727821>

Riesland, N. J. and Wilde, H. 2015. Expert review of evidence bases for managing monkey bites in travelers. Journal of Travel Medicine 22, 4: 259-262. $<$ https://doi.org/10.1111/jtm.12214>

Tsiresy, R. 1995. Rabies in Madagascar. Proceeding of the SEARG International Symposium. Available online <http://searg.info/fichiers/articles/1995045047L.PDF> Accessed 21 May 2017.

United Nations. 2017.Population Division. World Population Prospects 2017. Available at <https://esa.un.org/unpd/wpp/dataquery/>. Accessed 20 May 2018>

Valenta, K., Gettinger-Larson, J. A., Chapman, C. A. and Farris, Z. J. 2016. Barking up the right tree: understanding local attitudes towards dogs in villages surrounding Ranomafana National Park, Madagascar can benefit applied conservation. Madagascar Conservation \& Development 11, 2: 87-90. $<$ http://dx.doi.org/10.4314/mcd.v11i2.4>

World Health Organization. 2010. Rabies vaccines. WHO position paper. Weekly Epidemiological Record 85, 32: 309-320. Available at <http://www.who.int/wer/2010/wer8532/en/>

World Tourism Organization. 2014. International tourism, number of arrivals. Available at <http://data.worldbank.org/indicator/ST.INT.ARVL?locations=MG> Accessed 21 May 2017

Zeller, H. G., Rakoto-Andrianarivelo, M., Rakotonjanabelo, L. A. and Roux, J. F. 1999 Rabies in Madagascar: 1994-1998. Proceedings of the Southern and Eastern African Rabies Group/World Health Organization Meeting in Entebbe, Uganda 29-31 March, 1999, pp 58-62. Éditions Fondation Marcel Mérieux, Lyon, France. Available at <https://bit.ly/2Lt1KT6>

\section{SUPPLEMENTARY MATERIAL}

Available online only

Table S1. The primary and secondary sources from which IPM data were collected, including information on the information source, the year(s) for which this source provided information, and the type of information taken from this source.

Table S2. The number and percent of animals that tested positive for the rabies virus in tests conducted by the Institut Pasteur de Madagascar (IPM, samples typically sent to IPM by veterinarians). These lemurs were tested by the IPM because the animals were suspected as being rabies virus carriers (i.e., a human receiving PEP treatment from IPM indicated that the specific animal was the reason for seeking treatment).

Table S3: Information collected from patients about whether the lemur in question (i.e., the lemur which caused a person to receive PEP treatment at IPM) was a wild or pet lemur, as well as what happened to the lemur in question. Descriptions of lemurs are translated from the French language directly from IPM reports (noting that the IPM reports provided no further information about how lemurs were categorized into these different descriptions). 